\title{
Pengembangan Sistem Informasi Perusahaan Konveksi dan Sablon Berbasis Website Menggunakan Metode Waterfall Raja Sabaruddin ${ }^{1}$, Mely Juniarti ${ }^{2}$, Ardiyansyah ${ }^{3}$, Wahyu Nugraha ${ }^{4}$
}

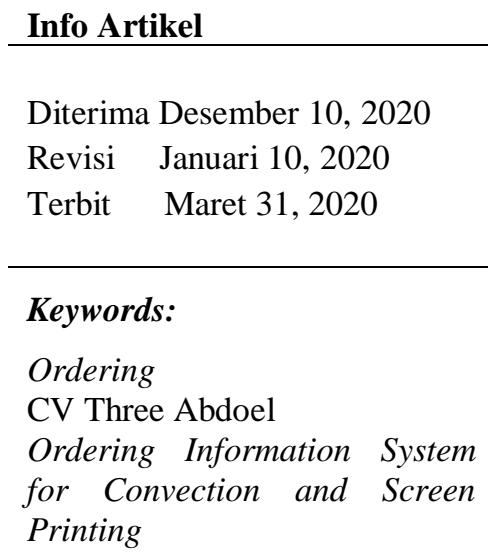

\section{Identitas Penulis:}

Raja Sabaruddin ${ }^{1}$, Mely Juniarti ${ }^{2}$, Ardiyansyah $^{3}$, Wahyu Nugraha ${ }^{4}$ Universitas Bina Sarana Informatika Program Studi Sistem Informasi Akuntansi Kampus Pontianak Jalan Abdurrahman Saleh no. 18 A Pontianak Raja.rjd@bsi.ac.id ${ }^{1}$, mjuniarti0@gmail.com ${ }^{2}$, ardiyansyah.arq@bsi.ac.id ${ }^{3}$,wahyu.whn@bsi.ac.id ${ }^{4}$

\section{PENDAHULUAN}

Teknologi informasi merupakan suatu kebutuhan yang dapat membantu kinerja perusahaan, organisasi maupun proses bisnis[1]. Teknologi yang semakin meningkat dengan banyaknya dukungan berupa sarana prasarana yang memadai, menjadikan informasi saat ini telah menjadi kebutuhan yang harus terpenuhi dalam kehidupan manusia, saat ini teknologi sudah bisa diakses hampir di seluruh penjuru dunia. Kemudahan dan biaya akses yang relatif murah inilah menjadikan sarana pemenuhan kebutuhan sistem informasi yang utama. Dengan adanya sistem informasi yang baik maka akan dapat melakukan dan menghasilkan informasi yang dibutuhkan dengan cepat dan akurat.[2]

Konveksi dan sablon termasuk dalam usaha mikro kecil dan menengah (UMKM) atau sering disebut sebagai industri rumahan. Usaha ini, biasanya tidak hanya memproduksi pakaian saja akan tetapi bermacammacam produk, misalnya konveksi kaos, seragam, baju olah raga almamater dan toga. Sedangkan pada penyablonan meliputi tas, topi, jaket, baju, sepatu, kaos, rompi, payung dan mug. Usaha konveksi dan sablon biasanya mendapatkan pesanan dalam jumlah besar pada momen-momen tertentu seperti menjelang lebaran, acara seremonial (membuat seragam panitia), dan pergantian tahun ajaran baru (membuat seragam sekolah, seragam olahraga atau seragam kelas).

Salah satu dari sekian banyak konveksi dan tempat sablon yang ada di Kubu Raya adalah CV. Three Abdoel. CV. Three Abdoel awal berdiri hanya berfokus pada pensablonan baju kaos, dan seiring berjalannya 
waktu juga memproduksi sablon rompi, topi, totebag, jaket dan goodiebag, serta konveksi seragam dan baju olahraga yang di order dari sekolah, perorangan, instansi pemerintah, lembaga pendidikan dan badan usaha.

Di era perkembangan teknologi informasi yang semakin canggih seperti saat ini CV. Three Abdoel belum menerapkan teknologi sistem informasi. Saat ini untuk pemesanan perusahaan hanya melayani pemesanan di tempat sehingga konsumen harus datang langsung ke lokasi. Hal ini dinilai kurang efektif sehingga berdampak kurangnya informasi produk yang didapat oleh konsumen.[3] Hal ini menjadi salah satu kendala dalam proses pemesanan karena dapat membatasi konsumen yang tertarik pada konveksi dan sablonan yang ditawarkan terutama pada konsumen yang bertempat tinggal jauh dari lokasi perusahaan. Selain itu proses pencatatan setelah pemesanan atau laporan dari hasil pemesanan dan penjualannya yang kurang efektif karena masih menggunakan tulis tangan, dan tidak adanya buku khusus untuk pencatatan mengakibatkan hilangnya datadata trasaksi atau laporan yang ada di perusahaan dan memperbesar peluang manipulasi data-data yang ada di perusahaan.

Beberapa penelitian terkait yang pernah dilakukan oleh penliti terdahulu, seperti penelitian yang di lakukan oleh Muhammad Riyan Abhad, dkk membuat sistem manajemen meggunakan metode prototype untuk proses pemesanan, manajemen produksi, dan pendataan keuangan. [4]. Selain itu di lakukan juga oleh Andri Prasetyo dan Rahel Susanti membuat sistem informasi penjualan online untuk proses pemasaran dan transaksi penjualan.[5].

Oleh karena itu sistem informasi yang sudah terkomputerisasi yang dapat memudahkan konsumen dalam memesan suatu produk konveksi dan sablon yang akan dipesan dan mencari tahu produk-produk yang disediakan dari perusahaan untuk dipesan oleh konsumen sehingga konsumen tidak perlu ke tempat untuk melakukan pemesanan dan juga memudahkan admin dan bendahara perusahaan dalam mengolah data-data pemesanan dan penjualan yang terjadi. Selain itu diharapkan informasi yang dihasilkan dan diterima lebih akurat dan meminimalisir kesalahan dalam proses pemesanan dan pencatatan laporan pemesanan yang terjadi di CV. Three Abdoel.

Berdasarkan permasalahan diatas, maka penelitian ini bertujuan membuat sistem informasi konveksi dan sablon pada CV Three Abdoel menggunakan website. Sehingga CV Three Abdoel dalam mengelola perusahanya semakin mudah dan cepat terutama dalam mengelola data produk, data konsumen, pemesanan dan penjualan.

\section{METODE}

Metode yang digunakan yaitu metode penelitian deskriptif yang merupakan penelitian menggambarkan objek atau subjek yang di teliti sesuai dengan yang terjadi. Untuk mendukung metode penelitian ini, digunakan tekhnik pengumpulan data dan metode pengembangan perangkat lunak.

\section{a. Metode pengumpulan Data}

Metode pengumpulan data merupakan kegiatan yang berkaitan dengan mengumpulkan data-data statistik dengan menggambarkan beberapa metode pengumpulan data, untuk memudahkan penulis dalam menyelesaikan penelitian penulis menggunakan teknik metode pengumpulan data yaitu observasi, wawancara, dokumentasi dan studi pustaka.[6] dan dapat di lihat seperti pada tabel 1 di bawah ini.

Tabel 1. Metode Pengumpulan Data

\begin{tabular}{|c|c|c|c|}
\hline Pegamatan (Observation) & Wawancara (Interview) & Dokumentasi (Documentation) & $\begin{array}{c}\text { Studi Pustaka (Literature } \\
\text { Review) }\end{array}$ \\
\hline $\begin{array}{l}\text { Pengamatan secara langsung } \\
\text { ke lokasi penelitian, melihat } \\
\text { proses kegiatan yang berjalan } \\
\text { seperti proses pemesanan yang } \\
\text { meliputi kegiatan pemilihan } \\
\text { bahan, warna, design, dan } \\
\text { harga sampai proses laporan } \\
\text { pemesanan produk dan laporan } \\
\text { penjualan produk, serta untuk } \\
\text { mendapatkan informasi lain } \\
\text { mengenai proses pemesanan } \\
\text { produk yang dilakukan pada } \\
\text { CV. Three Abdoel. Peneliti } \\
\text { juga mengamati web sejenis } \\
\text { atau aplikasi online shop } \\
\text { sebagai referensi seperti }\end{array}$ & $\begin{array}{l}\text { Penulis melakukan suatu } \\
\text { metode tanya jawab mengenai } \\
\text { kegiatan yang berhubungan } \\
\text { dengan perusahaan khususnya } \\
\text { kegiatan pemesanan produk } \\
\text { konveksi dan sablon } \\
\text { wawancara dilakukan dengan } \\
\text { Bapak Zulkarnaen Qafy, SH } \\
\text { selaku pemilik perusahaan. } \\
\text { Penulis menanyakan } \\
\text { pertanyaan seputar kegiatan } \\
\text { pemesanan yang dilakukan } \\
\text { oleh perusahaan, sistem bisnis } \\
\text { berjalan yang terjadi dan } \\
\text { berbagai data atau dokumen }\end{array}$ & $\begin{array}{lr}\text { Penulis } & \text { mendokumentasikan } \\
\text { data-data yang diperlukan } \\
\text { dengan mengambil gambar } \\
\text { dengan } & \text { menggunakan } \\
\text { Handphone atau kamera pada } \\
\text { dokumen-dokumen r yang } \\
\text { digunakan pada proses } \\
\text { pemesanan yang sedang } \\
\text { terjadi. Tujuan pengambilan } \\
\text { gambar adalah sebagai bukti } \\
\text { bahwa penelitian yang } \\
\text { dilakukan dan data-data yang } \\
\text { dicantumkan benar dan tidak } \\
\text { manipulasi. }\end{array}$ & $\begin{array}{l}\text { Penulis mencari data-data yang } \\
\text { diperlukan dengan mengkaji } \\
\text { sumber-sumber pustaka seperti } \\
\text { dari refensi buku-buku yang } \\
\text { ada di perpustakaan, jurnal dan } \\
\text { artikel-artikel yang ada di } \\
\text { internet untuk memenuhi data- } \\
\text { data yang diperlukan. }\end{array}$ \\
\hline
\end{tabular}


Shopee, Tokopedia dan Buka yang dipakai saat pemesanan

Lapak. $\quad$ produk.

Sumber: Hasil Penelitian(2019)

\section{b. Metode Pengembangan Software}

Metode pengembangan software yang digunakan adalah metode waterfall. Model air terjun (waterfall) sering juga disebut model sekuensial linier (sequential linear) atau alur hidup klasik (classic life cycle). Model air terjun menyediakan pendekatan alur hidup terurut mulai dari analisis kebutuhan perangkat lunak, desain, pengkodean program, pengujian, dan pendukung.[7]

Adapun tahap-tahap dari metode pengembangan software dapat dilihat pada tabel 2 seperti berikut :

Tabel 2. Metode Pengembangan Software

\begin{tabular}{ll}
\hline $\begin{array}{l}\text { Analisis } \\
\text { Kebutuhan } \\
\text { Perangkat Lunak } \\
\text { (Software) }\end{array}$ & $\begin{array}{l}\text { Analisis kebutuhan perangkat lunak merupakan proses pengumpulan kebutuhan secara intensif untuk } \\
\text { menspesifikasikan kenutuhan perangkat lunak. Dalam tahapan ini, penulis melakukan analisis kebutuhan yang } \\
\text { diperlukan dalam perancangan sistem pemesanan konveksi dan sablon, dimulai dari analisis kebutuhan } \\
\text { fungsional dan analisis kebutuhan non fungsional. Analisa kebutuhan perangkat lunak juga didasari dari data- } \\
\text { data yang diperoleh dari teknik-teknik pengumpulan data. }\end{array}$ \\
\hline Desain & $\begin{array}{l}\text { Desain perangkat lunak adalah proses multi langkah yang fokus pada desain pembuatan program perangkat } \\
\text { lunak yang terdiri dari rancangan sistem usulan yang digambarkan menggunakan Unified Modeling Language } \\
\text { (UML) seperti use case, activity diagram, class diagram dan } \text { user interface. }\end{array}$ \\
\hline Code Generation & $\begin{array}{l}\text { Rancangan sistem dijadikan sebagai pengimplementasikan atau pembuatan kode program. Tahapan ini } \\
\text { berkaitan dengan pengkodean (coding) menggunakan Sublime, PHP, HTML, CSS, dan Javascript untuk } \\
\text { menghasilkan sistem informasi yang berbasis web. }\end{array}$ \\
\hline $\begin{array}{l}\text { Pengujian } \\
\text { (Testing) }\end{array}$ & $\begin{array}{l}\text { Untuk meminimalisir kesalahan dan memastikan keluaran (output) yang hasilkan sesuai dengan yang di } \\
\text { inginkan diharapkan, maka penulis melakukan tahap pengujian yang berfokus pada sistem dari segi logika dan } \\
\text { fungsional dan memastikan bahwa semua bagian sudah diuji. Penulis menggunakan blackbox testing sebagai } \\
\text { metode pengujian perangkat lunak (software) dengan cara menguji halaman website dengan menggunakan } \\
\text { sebuah browser. }\end{array}$ \\
\hline
\end{tabular}

Sumber: Hasil Penelitian(2019)

\section{HASIL}

Adapun pada bagian hasil, penulis menjabarkan hasil-hasil yang di dapatkan berdasarkan metode pengembangan perangkat lunak. Yaitu UML seperti use case, activity diagram, class diagram dan user interface.

\subsection{Use Case Diagram}

\section{a. Use Case Diagram Direktur}

Admin masuk ke sistem kemudian dapat melihat Beranda, mengelola data customer, data kategori, data produk, data user, data pemesanan, laporan pemesanan dan laporan jurnal penjualan konveksi dan sablon. Setelah selesai direktur dapat keluar dari sistem. Use case diagram bisa di lihat pada gambar 1 di bawah ini.

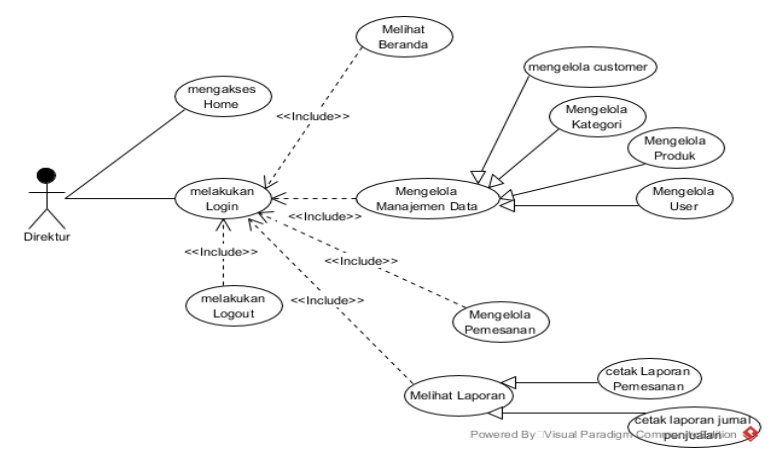

Sumber: Hasil Rancangan(2019)

\section{b. Use Case Diagram Admin}

Gambar 1. Use Case Diagram Direktur

Admin dapat masuk ke sistem kemudian dapat melihat Beranda, mengakses Manajemen Data yang meliputi mengelola data customer, data profil, data pemesanan dan melihat data produk. Use case diagram bisa di lihat pada gambar 2 di bawah ini. 


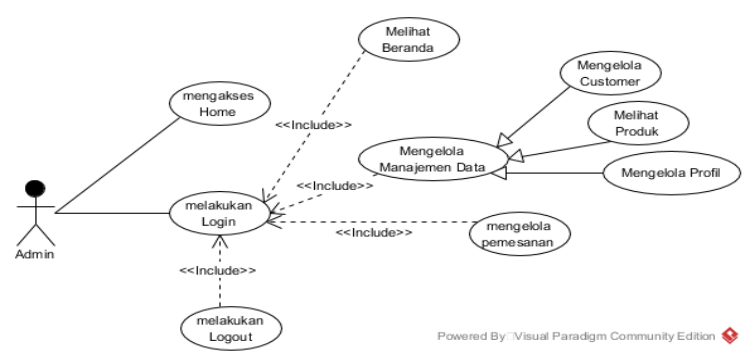

Sumber: hasil Rancangan(2019)

Gambar 2. Use Case Diagram Admin

\section{c. Use Case Diagram Costumer}

Customer dapat masuk ke halaman utama sistem web kemudian dapat melihat tampilan informasi dan registrasi. Setelah registrasi dan login customer dapat langsung kehalaman home, customer dapat langsung melakukan pemesanan produk, melihat Beranda, mengelola list pemesanan dan mengelola data pribadi. Use case diagram bisa di lihat pada gambar 3 di bawah ini.

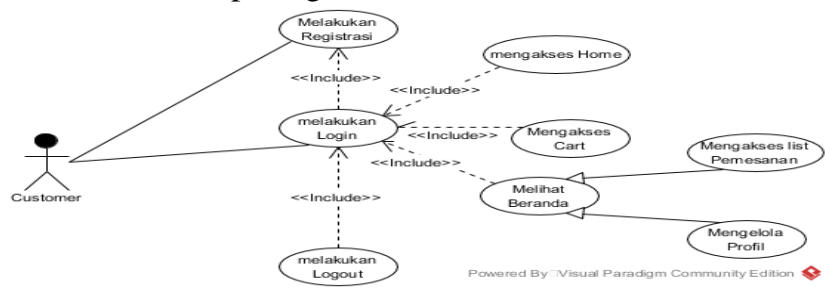

Sumber: Hasil Rancangan(2019)

\subsection{Activity Diagram}

Gambar 3. Use Case Diagram Costumer

a. Activity Diagram Login Direktur dan Admin

Adapun activity diagram bisa dilihat seperti di bawah ini pada gambar 4 .

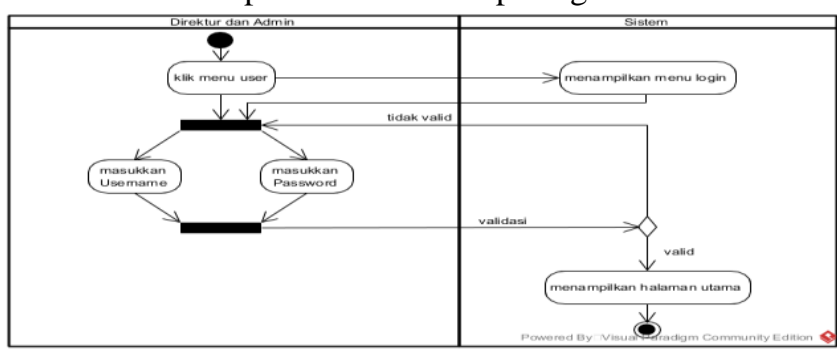

Sumber: Hasil Penelitian(2019)

Gambar 4. Activity diagram login direktur dan admin.

b. Activity Diagram Menu Utama Direktur

Adapun activity diagram bisa dilihat seperti di bawah ini pada gambar 5 .

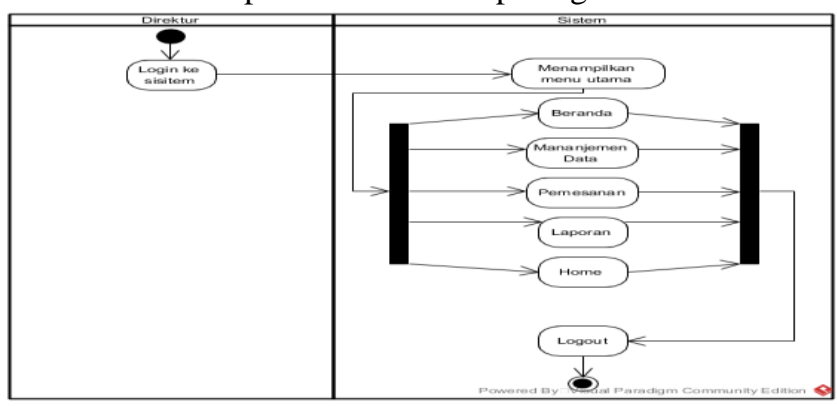


Sumber: Hasil Penelitian(2019)

Gambar 5. Activity Diagram Menu Utama Direktur.

c. Activity Diagram Menu Utama Admin

Adapun activity diagram bisa dilihat seperti di bawah ini pada gambar 6 .

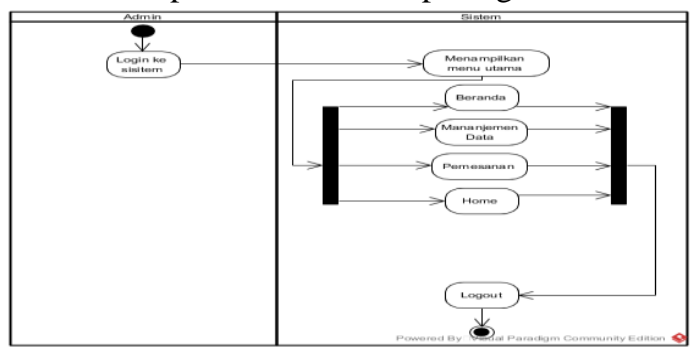

Sumber: Hasil Penelitian(2019)

Gambar 6. Activity Diagram Menu Admin

d. Activity Diagram Menu Pemesanan Direktur dan Admin

Adapun activity diagram bisa dilihat seperti di bawah ini pada gambar 7 .

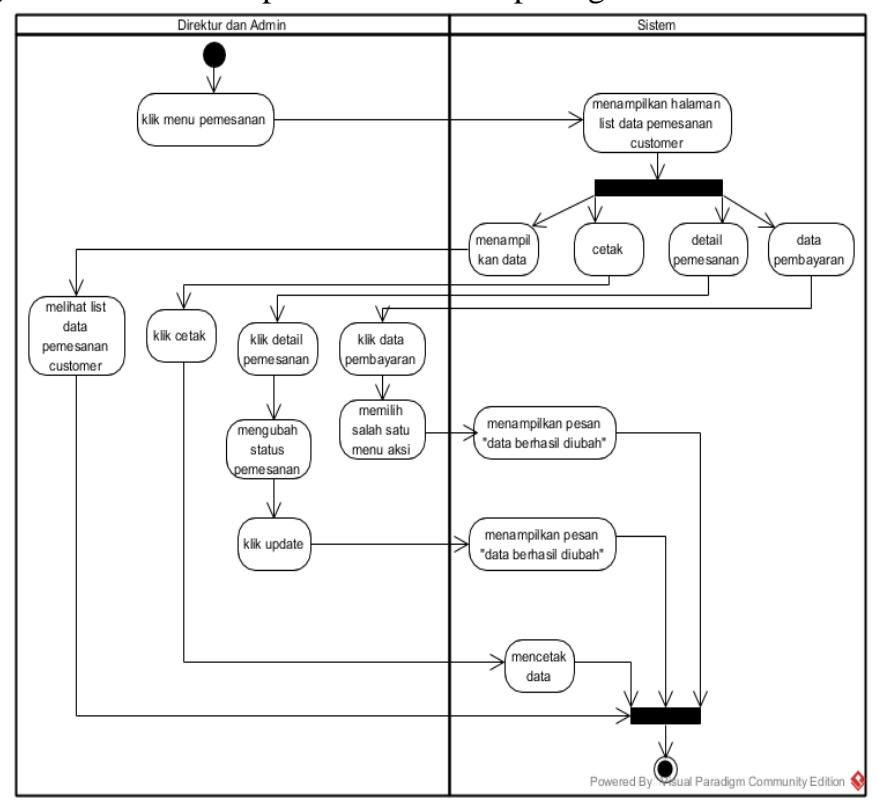

Sumber: Hasil Penelitian(2019)

Gambar 7. Activity Diagram Pemesanan Direktur dan Admin.

e. Activity Diagram Laporan Pemesanan pada Direktur

Adapun activity diagram bisa dilihat seperti di bawah ini pada gambar 8 .

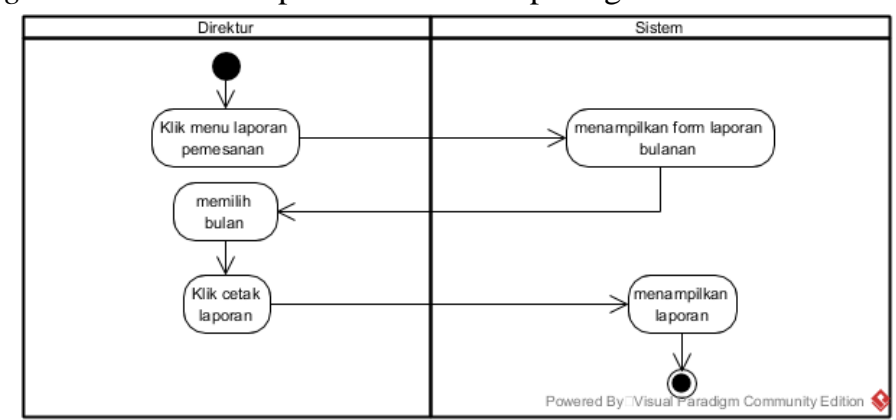

Sumber: Hasil Penelitian(2019) 
Gambar 8. Activity Diagram Laporan pada Pemesanan Direktur.

f. Activity Diagram Laporan Jurnal Penjualan

Adapun activity diagram bisa dilihat seperti di bawah ini pada gambar 9 .

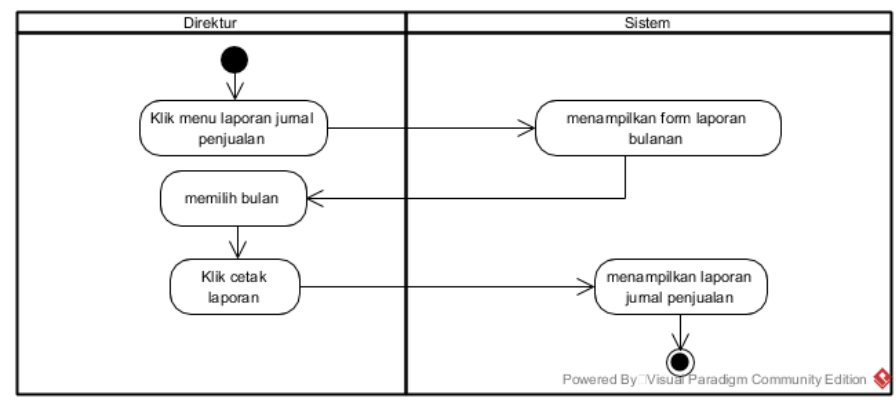

Sumber: Hasil Penelitian(2019)

Gambar 9. Activity Diagram Jurnal Penjualan.

g. Activity Diagram Pemesanan pada Customer

Adapun activity diagram bisa dilihat seperti di bawah ini pada gambar 10 .

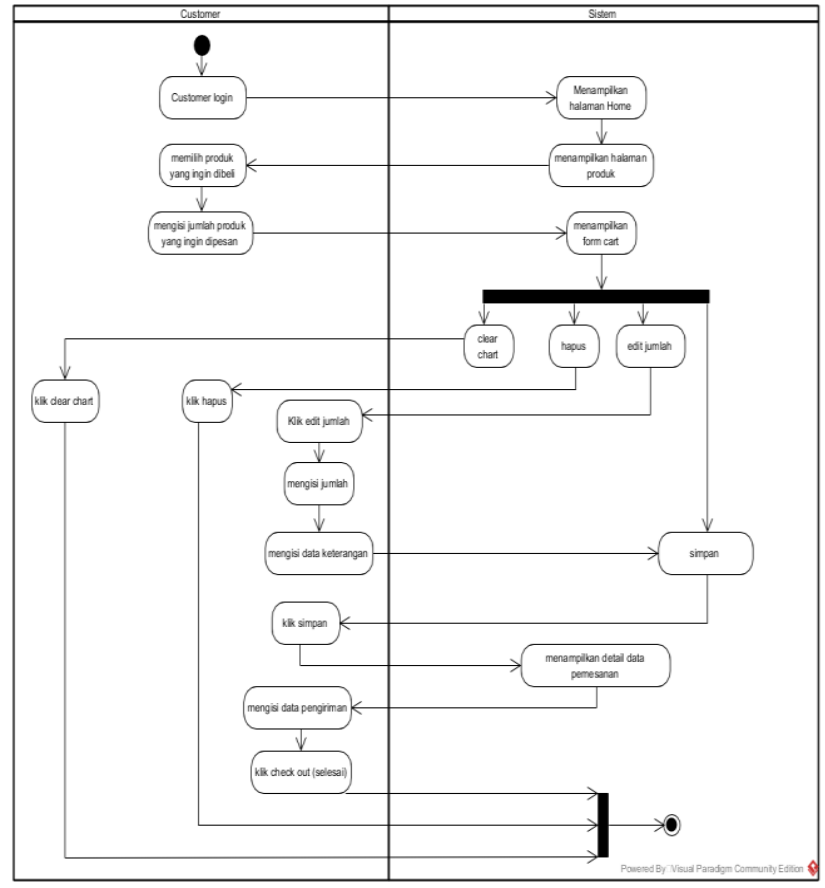

Sumber: Hasil Penelitian(2019)

Gambar 10. Activity Diagram Pemesanan pada Customer.

h. Activity Diagram Menu List Pemesanan pada Customer

Adapun activity diagram bisa dilihat seperti di bawah ini pada gambar 11 . 


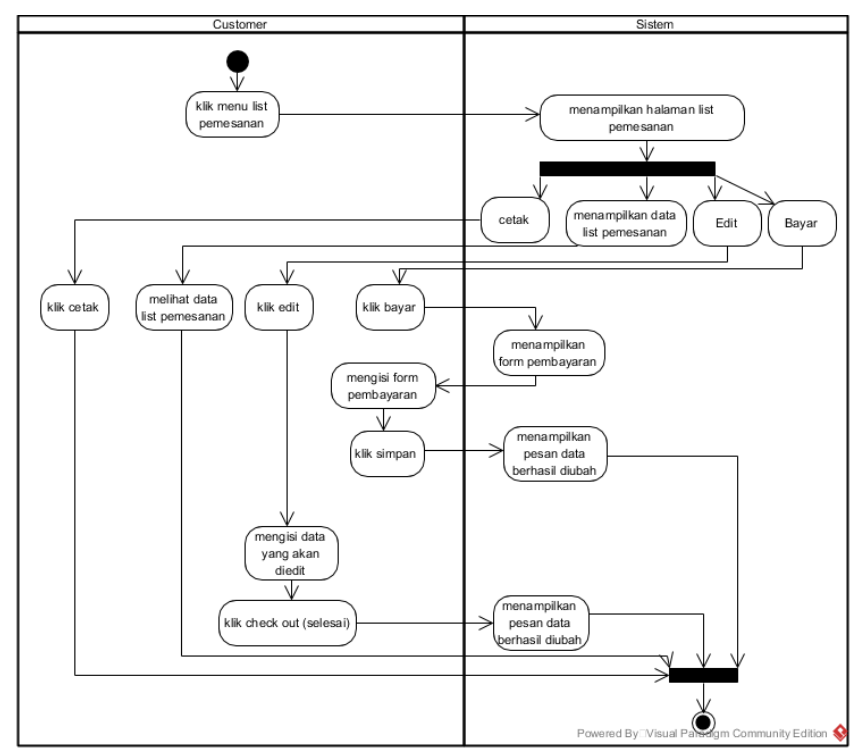

Sumber: Hasil Penelitian(2019)

Gambar 11. Activity Diagram Menu List Pemesanan pada Customer.

\subsection{Class Diagram}

Berikut class diagram pada CV Three Abdoel, terlihat pada gambar 12 berikut ini.

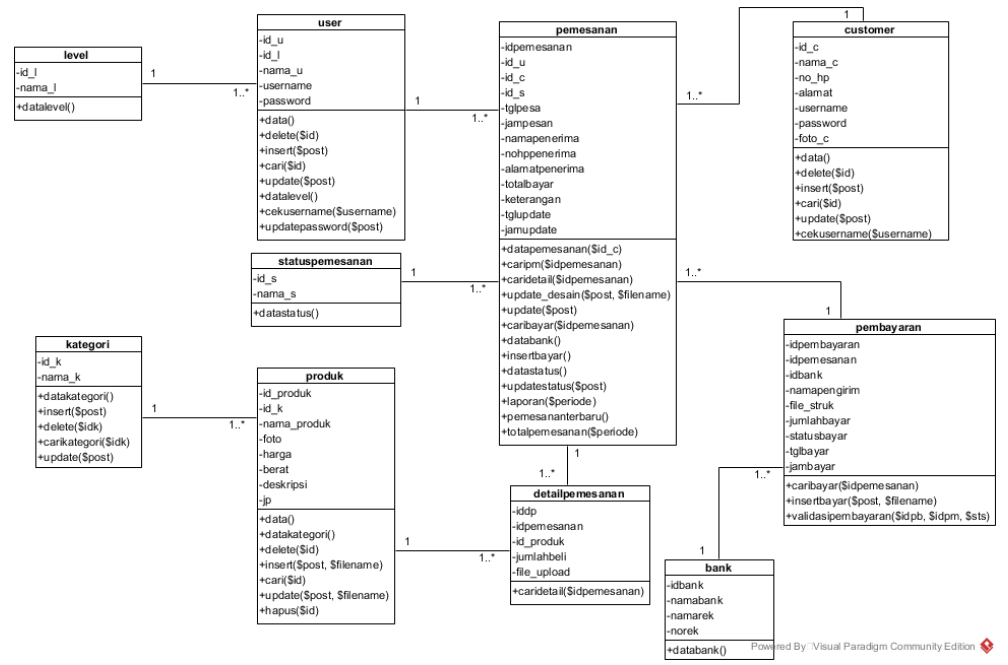

Sumber: Hasil Penelitian(2019)

\subsection{User Interface}

Gambar 12. Class Diagram

Antarmuka (interface) merupakan mekanisme komunikasi antaran pengguna (user dan customer) dengan sistem. Antarmuka (interface) dapat menerima informasi dari pengguna (user dan customer) dan memberikan informasi kepada pengguna (user dan customer) untuk membantu mengarahkan alur penelusuran masalah sampai ditemukan suatu solusi. Rancangan antarmuka pada sistem informasi pemesanan konveksi dan sablon pada CV. Three Abdoel berbasis Web sebagai berikut :

1. User Interface Halaman Utama

User interface halaman utama dapat di lihat pada gambar 13 berikut ini. 


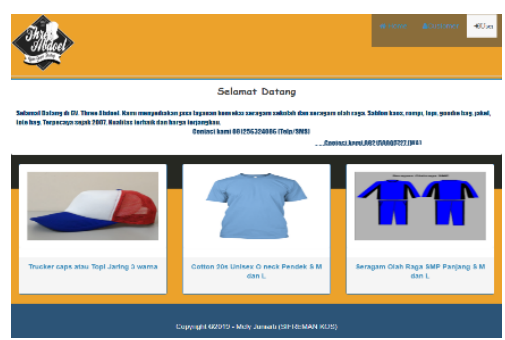

Sumber: Hasil Penelitian(2019)

Gambar 13. User Interface Halaman Utama

2. User Interface Keranjang Belanja

User interface keranjang belanja dapat di lihat pada gambar 14 berikut ini.

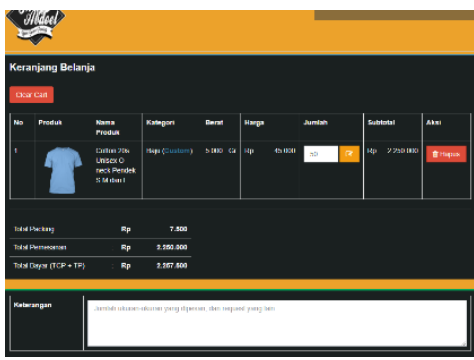

Sumber: Hasil Penelitian(2019)

Gambar 14. User Interface Keranjang Belanja

3. User Interface Pembayaran

User interface pembayaran dapat di lihat pada gambar 15 berikut ini.

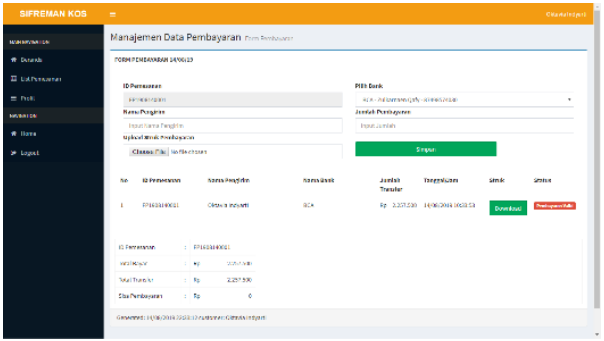

Sumber: Hasil Penelitian(2019)

Gambar 15. User Interface Pembayaran

4. User Interface Validasi Pemesanan

User interface validasi pemesanan dapat di lihat pada gambar 16 berikut ini.

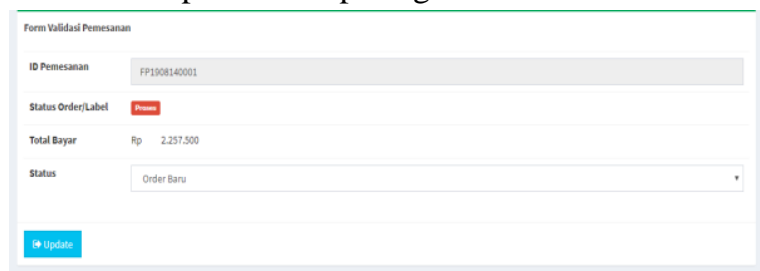

Sumber: Hasil Penelitian(2019)

Gambar 16. User Interface Validasi Pemesanan

5. User Interface Hasil Laporan Bulanan

User interface laporan bulanan dapat di lihat pada gambar 17 berikut ini. 


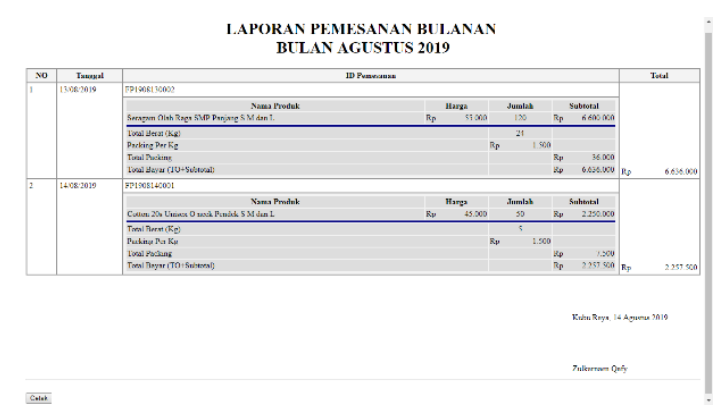

Sumber: Hasil Penelitian(2019)

Gambar 17. User Interface Hasil Laporan Bulanan

6. User Interface Hasil Laporan Jurnal Penjualan

User interface laporan jurnal dapat di lihat pada gambar 18 berikut ini.

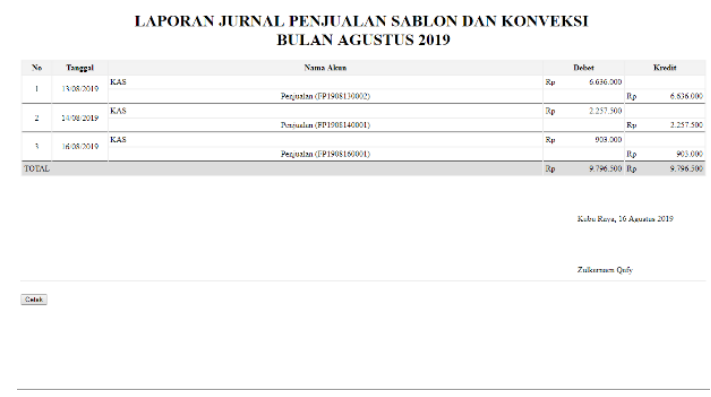

Sumber: Hasil Penelitian(2019)

Gambar 18. User Interface Hasil Laporan Jurnal Penjualan

\section{KESIMPULAN}

Pada pembahasan bab-bab sebelumnya mengenai sistem informasi pemesanan konveksi dan sablon pada $\mathrm{CV}$. Three Abdoel maka penulis memberikan beberapa kesimpulan yang di ambil dari tinjauan-tinjauan bab sebelumnya, yaitu Sistem informasi pemesanan konveksi dan sablon dibuat berbasis web untuk dikelola oleh 3 pengguna, yaitu direktur, admin dan customer. Sistem informasi pemesanan konveksi dan sablon yang dibuat ini terdiri dari pencatatan data, data user, data customer, data produk, data kategori, data pemesanan, data list pemesanan, laporan pemesanan, melakukan pemesanan, mengelola data profil. Dimana aplikasi dapat diakses oleh direktur dan admin untuk bagian internal perusahaan dan customer. Direktur dapat mengelola semua data yang ada meliputi data, level, data kategori, data produk, data user, data customer, data pemesanan, laporan pemesanan dan laporan jurnal. Admin dapat mengelola data customer, profil pribadi, data pemesanan, laporan pemesanan dan melihat produk. Sedangkan customer dapat melakukan pemesanan, mengelola profil pribadi, mengelola list pemesanan. Keluaran yang dihasilkan dari sistem informasi pemesanan konveksi dan sablon ini yaitu laporan pemesanan. Manfaat dari sistem informasi pemesanan konveksi dan sablon adalah untuk memudahkan dan mengurangi kesalahan user dalam melakukan pencatatan data dan transaksi serta penyimpanan data yang aman dan dijamin keakuratannya dan pada customer tetap dapat melakukan pemesanan meskipun bertempat tinggal jauh dari perusahaan.

\section{REFERENSI}

[1] N. Alannita and I. Suaryana, "Pengaruh Kecanggihan Teknologi Informasi, Partisipasi Manajemen, Dan Kemampuan Teknik Pemakai Sistem Informasi Akuntansi Pada Kinerja Individu,” E-Jurnal Akunt., vol. 6, no. 1, pp. 33-45, 2014.

[2] R. Murni, Sri, Latifah, Fransiska, Endah, Apriana Dede, Sabaruddin, "Pemanfaatan sistem informasi akuntansi dalam perhitungan pendapatan atas hutang anggota koperasi," vol. VII, no. 2, pp. 120-127, 2019.

[3] L. Lisnawanty, I. Khaldun, and W. Irmayani, "Aplikasi Laporan Keuangan Dinas Pendapatan Pengelolaan Keuangan Dan Aset Daerah (DPPKAD) Kabupaten Pontianak," J. Tek. Inform. Musirawas, vol. 3, no. 1, p. 50, 2018, doi: 10.32767/jutim.v3i1.306.

[4] D. P. Muhamad Rayyan Abhad, Achmad Arwan, "PengembanganSistem Manajemen Perusahaan Sablon Kaos Berbasis WebsiteMenggunakan Metode Prototyping.” pp. 8514-8522, 2019. 
[5] A. Prasetyo and R. Susanti, "Sistem Informasi Penjualan Berbasis Web Pada PT. Cahaya Sejahtera Sentosa Blitar," J. Ilm. Teknol. Inf. Asia, vol. 10, no. 2, pp. 1-16, 2016.

[6] S. Ramadhani, U. Anis, S. T. Masmuro, and ., "Rancang Bangun Sistem Informasi Geografis Layanan Kesehatan Di Kecamatan Lamongan Dengan PHP MySQL,” J. Tek., vol. 5, no. MYsql, pp. 479-484, 2013, doi: 10.1007/978-1-62703-471-5_1.

[7] R. Sabaruddin and S. Murni, "Rancang Bangun Aplikasi Asuransi Mobil Dengan Pendekatan Metode Waterfall,” J. Tek. Inform. Musirawas, vol. 3, no. 2, p. 99, 2018, doi: 10.32767/jutim.v3i2.365. 